\title{
Quantitative Analysis of Caffeine Levels in Local Coffee (Coffea sp) Powder on Dabo Island with UV-Vis Spectrophotometry
}

Sri Hainil
Suhaera*
Lirtri
Department of Pharmacy, Sekolah
Tinggi Ilmu Kesehatan Mitra Bunda
Persada Batam, Batam, Riau Island,
Indonesia
*email: emilsalimhera@gmail.com
Keywords:
Caffeine
Coffee Powder
Spectrophotometry UV-Vis

\begin{abstract}
Coffee (Coffea sp) is the second-largest beverage consumed by people around the world whose process comes from the processing and extraction of coffee beans. Coffee has a chemical compound, one of which is caffeine. Caffeine is a crystal-shaped compound. Caffeine can be a tangible white powder or a shiny white needle-shaped, odorless caffeine, and caffeine has a bitter taste. The purpose of the study was to determine the caffeine levels of local ground coffee on the island of Dabo with the spectrophotometry UV-Vis method. Analysis of the ground coffee caffeine levels is quantitative determined using spectrophotometry UV-Vis. The equation of the calibration curve of caffeine is regression $y=0.1307 x+0.0112$ with a correlation coefficient value (r) of 0.9993. Based on Indonesian National Standards (SNI) 017152-2006, The maximum limit of caffeine in foods and beverages is $150 \mathrm{mg} /$ day and $50 \mathrm{mg} /$ serving. The results of the analysis of caffeine levels from three samples of ground coffee circulating on Dabo Island each in $2 \mathrm{~g}$ were $0.3383 \mathrm{mg}$ for Sample A; $0.3786 \mathrm{mg}$ for Sample B; and $0.5803 \mathrm{mg}$ for Sample C.
\end{abstract}

Received: August 7th 2019

Accepted: October 12th 2019

Published: November 14th 2019

(C) 2019 Sri Hainil, Suhaera, Lirtri. Published by Institute for Research and Community Services Universitas Muhammadiyah Palangkaraya. This is an Open Access article under the CC-BY-SA License (http://creativecommons.org/licenses/by-sa/4.0/). DOI: https://doi.org/10.33084/bjop.v2i2.897.

\section{INTRODUCTION}

Coffee (Coffea sp) is a type of beverage that process comes from the processing of coffee beans. Nowadays, coffee is the second-largest beverage consumed by people all over the world, after water (Gaascht et al., 2015). Coffee has many benefits for health if used within reasonable limits, such as reducing headaches, coffee aroma relieving stress, caffeine coffee prevents cavities, relieve people with asthma, enrich the body's antioxidants, protect the skin, and stimulate brain work (Temple et al., 2017).

Coffee has one compound content that is caffeine. Caffeine is one of the many types of alkaloids found in coffee beans, tea leaves, and cocoa beans (Wilson, 2018). Caffeine is a white crystalline compound. The main constituent of protein derived compounds are called Purin xanthine (Arwangga et al., 2016). Based on
Indonesian National Standards (SNI) 01-7152-2006 The maximum limit of caffeine in foods and beverages is 150 $\mathrm{mg} /$ day and $50 \mathrm{mg} /$ serving (Fajara \& Susanti, 2017). This caffeine compound in normal body condition does have some efficacy among others is an analytic medication that can lower the pain and reduce fever (Grgic et al., 2018). However, on the body that also has problems with the presence of uric acid metabolism hormone, the content of caffeine in the body will trigger the formation of high uric acid (Pasalic et al., 2012).

Research on the determination of caffeine levels in coffee has been done by the method of UV-Vis spectrophotometry. The research from Aptika et al. (2015) on the sample of the coffee powder in the check using UV-Vis spectrophotometry method obtained by the result of caffeine content consumed by the people of 
Banjar Lebah, Bukian Village amounting from 647.5 to $690.9 \mathrm{mg}$, where the rate of caffeine passes the maximum limit according to SNI 01-7152-2006 which is 50 $\mathrm{mg} /$ serving or $150 \mathrm{mg} /$ day. From the research of Arwangga et al. (2016), levels of caffeine in coffee in Sesaot Narmada Village raw coffee $1.28 \pm 0.82 \%$ with water content of $3 \%$, pure coffee of $1.63 \pm 0.13 \%$ with water content of $1 \%$, and mixed coffee of $0.87 \pm 0.01 \%$ with water content of $1 \%$. Based on the breakdown of research results above, researchers are interested in researching quantitative analysis of caffeine levels in some local coffee powder from Dabo Island with UV-Vis spectrophotometry method.

\section{MATERIALS AND METHODS}

The materials used in this research are samples of powdered coffee, caffeine standard, aquadest, chloroform, and calcium carbonate. The samples used in this study consisted of three ground coffee specimens obtained from three different places on Dabo Island, namely samples A, B, and C. The tools used in this research are UV-Vis spectrophotometers (Shimadzu ${ }^{\circledR}$ UV 1800), Analytical scales $\left(K^{2} k_{0}{ }^{\circledR}\right)$, water bath, separating funnel, measuring flask (Iwaki ${ }^{\circledR}$ ), drip dropper $\left(\operatorname{Normax}^{\circledR}\right)$, Beaker Glass (Iwaki $\left.{ }^{\circledR}\right)$, hot plate, Erlenmeyer, measuring cup ( Iwaki ${ }^{\circledR}$ ), Spatula, stirring rods, and filter paper.

\section{Preparation of standard solutions}

Caffeine standards of $250 \mathrm{mg}$ are weighed and then entered in $250 \mathrm{ml}$ measuring flasks. The standard is then dissolved in distilled water to the limit then homogenized by shaking. A total of $2.5 \mathrm{ml}$ of the solution is then taken with a measuring pipette and then transferred in a $25 \mathrm{ml}$ measuring flask. The solution is then diluted with distilled water to the limit and homogenized to obtain a standard solution of $100 \mathrm{ppm}$ (Maramis et al., 2013).

\section{Determination of the maximum wavelength}

Uptake of $1 \mathrm{ml}$ of standard solution was measured using a UV-Vis spectrophotometer with a wavelength range of 200-400 $\mathrm{nm}$ and blanks in the form of aquadest. The maximum wavelength obtained is $205.4 \mathrm{~nm}$.

\section{Determination of the calibration curve}

Work standards are made by making a series of six solutions, each with a concentration of $2 ; 3 ; 4 ; 5$; and 6 ppm. Each is made by taking as much as $2 ; 3 ; 4 ; 5 ;$ and 6 $\mathrm{ml}$ of standard solution respectively, then transferred to a $100 \mathrm{ml}$ volumetric flask and dissolved with distilled water to the limit and homogenized.

\section{Sample preparation}

A total of $2 \mathrm{~g}$ of coffee powder from all three samples used was inserted into $250 \mathrm{ml}$ Erlenmeyer then added $150 \mathrm{ml}$ of hot aquadest and stirred. A hot coffee solution is filtered through the mouthpiece with a filter paper so that the coffee grounds do not carry over. The coffee solution was added with $1.5 \mathrm{~g}$ of calcium carbonate and inserted into the separating funnel and then extracted with $25 \mathrm{ml}$ of chloroform and repeated three times. The chloroform phase at the bottom is then taken and concentrated over the water bath until the chloroform completely evaporates.

\section{Determination of caffeine concentration}

The prepared sample was dissolved in $1 \mathrm{ml}$ of distilled water and then transferred in a cuvette. The sample is then measured for absorption with a UV-Vis spectrophotometer at the maximum wavelength that has been obtained previously.

\section{RESULTS AND DISCUSSION}

\section{Determination of the calibration curve}

Determination of the maximum wavelength obtained at the determination of the level of caffeine is used to make calibration curves, resulting in accuracy at high 
concentrations, thereby reducing placement errors or wavelength readings and obtaining maximum absorbance accuracy (Bhawani et al., 2015; Ahmed et al., 2015). Calibration curve determination has been done at a concentration of 2; 3; 4; 5 ; and 6 ppm. After obtaining the results of the measurement of absorption for caffeine raw solution, then the absorption is made of interference linearity curve to the concentration of the raw solution of caffeine to obtain line equation and linear regression. The absorbance value of the standard solution shows results in the range between 0.2 to $0.8 \AA$. The range is the range commonly used in determining the UV-Vis spectrophotometer calibration curve related to the accuracy of the results obtained (Khoshneviszadeh et al., 2015). The calibration curve obtained a linear relationship between concentration and absorption by the coefficient of correlation ( $r$ ) is 0.9993 and the equation of the regression line $y=0.1307 x+0.0112$. A value of $r$ which is getting closer to 1 indicates that the calibration curve that is formed is more linear, indicating a better equation (Bewick et al., 2003). The calibration curve is presented in Figure 1.

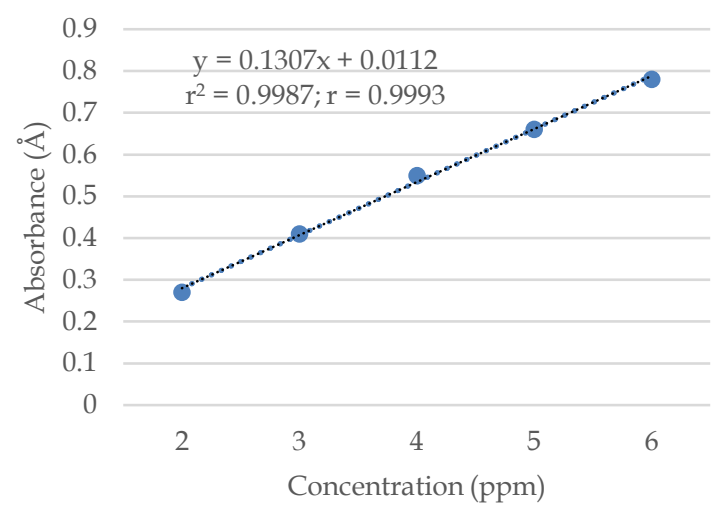

Figure 1. Calibration curves for standard caffeine solutions

\section{Determination of caffeine concentration}

Measurements of each sample showed varied results, where between Samples A and B showed close results, while Sample C showed the highest absorbance. As in the determination of the calibration curve, the absorbance of each sample also does not exceed $0.8 \AA$. That is because the absorbance that is too large can affect readings, especially on UV-Vis spectrophotometers with low resolution (Pratama et al., 2018).

The calculation of caffeine concentration in the sample is carried out using an equation that has been obtained previously. From the calculations, the concentration of caffeine from the sample is in the range of 0.1691 to 0.2902 $\mathrm{mg} / \mathrm{g}$ of coffee samples or as much as 0.3383 to $0.5803 \mathrm{mg}$ per packet of $2 \mathrm{~g}$. The highest concentration is shown in Sample C, while the lowest is shown in Sample A. The absorbance results, as well as the calculation of concentration, are shown in Table I.

Table I. Absorbance and calculation of caffeine concentration in coffee samples

\begin{tabular}{|c|c|c|c|c|}
\hline 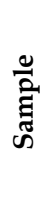 & 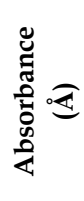 & 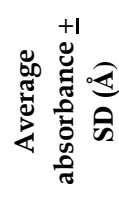 & 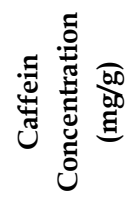 & 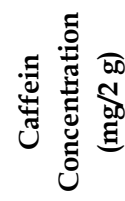 \\
\hline A & $\begin{array}{l}0.452 \\
0.453 \\
0.455\end{array}$ & $\begin{array}{c}0.453 \pm \\
0.0015\end{array}$ & 0.1691 & 0.3383 \\
\hline B & $\begin{array}{l}0.502 \\
0.509 \\
0.507\end{array}$ & $\begin{array}{c}0.506 \pm \\
0.0036\end{array}$ & 0.1893 & 0.3786 \\
\hline C & $\begin{array}{l}0.769 \\
0.771 \\
0.769\end{array}$ & $\begin{array}{r}0.770 \pm \\
0.0012\end{array}$ & 0.2902 & 0.5803 \\
\hline
\end{tabular}

The caffeine content of each sample itself is relatively not too high when compared to the maximum intake limit allowed by the Food and Drug Administration (FDA), which is between $100-200 \mathrm{mg} /$ day. The range is equivalent to 591 to $689 \mathrm{~g}$ of samples that can be consumed daily (Reyes \& Cornelis, 2018). When compared with SNI standards which require a maximum of the caffeine of $150 \mathrm{mg} /$ day and 50 $\mathrm{mg} /$ serving, the value is equivalent to a sample of 516 $\mathrm{g} /$ day and $172 \mathrm{~g} /$ serving. This amount is quite a lot when compared to the amount of ground coffee used to brew a glass of coffee which is about $2 \mathrm{~g} /$ serving (Fajara \& Susanti, 2017; Maramis et al., 2013). Some of the side 
effects that often occur due to caffeine intake include palpitations, insomnia, headaches, tremors, anxiety, seizures, arrhythmias, nausea, and vomiting. Besides, the consumption of regular caffeine, especially in large quantities, can cause dependency effects (Cornelis, 2019; Wassef et al., 2017).

\section{CONCLUSION}

Of the three coffee samples marketed on Dabo Island that were tested, all three met the SNI requirements. The caffeine content in Sample A was recorded at 0.3383 $\mathrm{mg} / 2 \mathrm{~g}$ of the sample; in Sample B $0.3786 \mathrm{mg} / 2 \mathrm{~g}$ of the sample; and in Sample C $0.5803 \mathrm{mg} / 2 \mathrm{~g}$ of sample. Further testing with other methods that have higher accuracy, such as HPLC can be done to ascertain the caffeine content of each coffee powder sample.

\section{REFERENCES}

Ahmed, S., Mustaan, N., Sheraz, M.A., Nabi, S.A.A., Ahmad, I. 2015. Validation of a UV Spectrometric Method for the Assay of Tolfenamic Acid in Organic Solvents. Journal of Pharmaceutics.

2015:216249. https:/ /dx.doi.org/10.1155/2015/216249

Aptika, N.M.D., Tunas, I.K., Sutema, I.A.M.P. 2015. Analisis kadar kafein pada kopi hitam di bukian gianyar menggunakan spektrofotometer UV-Vis. Jurnal Chemistry Laboratory. 2(1):30-37.

Arwangga, A.F., Asih, I.A.R.A., Sudiarta, I.W. 2016. Analisis Kafein pada Kopi di Desa Sesaot Narmada Menggunakan Spektrofotometri UV-Vis. Jumal Kimia (Journal of Chemistry). 10(1):110-114.

Bewick, V., Cheek, L., Ball, J. 2003. Statistics review 7: Correlation and regression. Critical Care. 7(6):451-459. https://dx.doi.org/10.1186/cc2401

Bhawani, S.A., Fong, S.S., Ibrahim, M.N.M. 2015. Spectrophotometric Analysis of Caffeine. International Journal of Analytical Chemistry.
2015:170239.

https:/ /dx.doi.org/10.1155/2015/170239

Cornelis, M.C. 2019. The Impact of Caffeine and Coffee on Human Health. Nutrients. 11(2):416. https://dx.doi.org/10.3390/nu11020416

Fajara, B.E.P., Susanti, H. 2017. HPLC determination of caffeine in coffee beverage. IOP Conference Series: Materials Science and Engineering. 259(2017):012011.

https://doi.org/10.1088/1757899X/259/1/012011

Gaascht, F., Dicato, M., Diederich, M. 2015. Coffee provides a natural multitarget pharmacopeia against the hallmarks of cancer. Genes $\mathcal{E}$ Nutrition. $\quad$ 10(6):51. https://dx.doi.org/10.1007/s12263-015-05013

Grgic, J. Trexler, E.T., Lazinica, B., Pedisic, Z. 2018. Effects of caffeine intake on muscle strength and power: a systematic review and meta-analysis. Journal of the International Society of Sports Nutrition.

15:11. https:/ /dx.doi.org/10.1186/s12970-018-02160

Khoshneviszadeh, R., Bazzaz, B.S.F., Housaindokht, M.R., Ebrahim-Habibi, A., Rajabi, O. 2015. UV Spectrophotometric Determination and Validation of Hydroquinone in Liposome. Iranian Journal of Pharmaceutical Research. 14(2):473-478.

Maramis, R.K., Citraningtyas, G., Wehantouw, F. 2013. Analisis Kafein dalam Kopi Bubuk di Kota Manado Menggunakan Spektrofotometri UVVis. Pharmacon. 2(4):122-128.

Pasalic, D., Marinkovic, N., Feher-Turkovic, L. 2012. Uric acid as one of the important factors in multifactorial disorders - facts and controversies. Biochemia Medica. 22(1):63-75. https://doi.org/10.11613/BM.2012.007

Pratama, M.R.F., Suratno, Mulyani, E. 2018. Profile of Thin-Layer Chromatography and UV-Vis Spectrophotometry of Akar Kuning Stem Extract (Arcangelisia flava). Borneo Journal of Pharmacy. 1(2):72-76. https://doi.org/10.33084/bjop.v1i2.367

Reyes, C.M., Cornelis, M.C. 2018. Caffeine in the Diet: Country-Level Consumption and Guidelines. 
Nutrients. $\quad$ 10(11):1772.

https://dx.doi.org/10.3390/nu10111772

Temple, J.L., Bernard, C., Lipshultz, S.E., Czachor, J.D., Westphal, J.A., Mestre, M.A. 2017. The Safety of Ingested Caffeine: A Comprehensive Review. Frontiers in Psychiatry. 8:80. https://dx.doi.org/10.3389/fpsyt.2017.00080

Wassef, B., Kohansieh, M., Makaryus, A.N. 2017. Effects of energy drinks on the cardiovascular system. World Journal of Cardiology. 9(11):796-806. https://dx.doi.org/10.4330/wjc.v9.i11.796

Wilson, C. 2018. The clinical toxicology of caffeine: A review and case study. Toxicology Reports. 5:1140-1152.

https://dx.doi.org/10.1016/j.toxrep.2018.11.0 02 